\title{
PROSES PENYUSUNAN ANGGARAN UNTUK MEWUJUDKAN KINERJA DAN KEPUASAN KERJA BERBASIS PARTISIPASI DI UNIVERSITAS TEUKU UMAR
}

\author{
Ferawilyanti $^{1}$, Bambang Supriyono ${ }^{2}$, Mochammad Rozikin ${ }^{3}$ \\ Program Magister Manajemen Pendidikan Tinggi, Fakultas Ilmu Administrasi, Universitas Brawijaya \\ Email: ferawilyanti.se@gmail.com ${ }^{1}$, bambangsupriyono@ub.ac.id ${ }^{2}$, mochammadrozikin@ub.ac.id ${ }^{3}$
}

\begin{abstract}
Higher education prioritizes quality in achieving the vision and mission, achieving the vision and mission is strongly influenced by the strength of the budget owned by a college. The strength of the budget is not only seen from how much the existing budget is, but also how the wisest way to manage the budget. This research is motivated by the limited budget owned by a new state university in managing the budget in a participatory manner in achieving the university's vision and mission. For this reason, a participatory system is needed for the budgeting process, starting from the planning stage, the process, accountability and results that lead to the university's vision and mission. The study was conducted to obtain information on whether participatory budgeting has an influence on employee performance, whether participatory budgeting also has an impact on employee job satisfaction at Teuku Umar University, also seeing whether there is an effect of employee job satisfaction on employee performance. This study also wants to find out whether there is an influence of motivation on employee performance, the influence of participatory budget on employee performance through motivation, and whether employee job satisfaction affects employee performance through motivation.
\end{abstract}

Key Words: Participatory Budget, performance, job satisfaction, and job motivation.

\begin{abstract}
ABSTRAK
Perguruan tinggi sangat mengutamakan mutu dalam mencapai visi misi, pencapaian visi misi sangat dipengaruhi oleh kekuatan anggaran yang dimiliki oleh sebuah perguruan tinggi. Kekuatan anggaran tidak hanya dilihat dari seberapa besar anggaran yang ada, namun juga bagaimana cara yang paling bijaksana dalam mengelola anggaran tersebut. Penelitian ini dilatarbelakangi oleh keterbatasan anggaran yang dimiliki oleh sebuah perguruan tinggi negeri baru dalam mengelola anggaran secara partisipatif dalam mencapai visi misi universitas. Untuk itu diperlukan sistem partisipatif untuk proses penyusunan anggaran, mulai dari tahap perencanaan, proses, pertanggung jawaban, serta hasil yang mengarah kepada visi misi universitas. Penelitian dilakukan untuk mendapatkan informasi benarkah anggaran partisipatif mempunyai pengaruh terhadap kinerja karyawan, apakah anggaran partisipatif (participatory budget) juga berdampak terhadap kepuasan kerja pegawai di Universitas Teuku Umar, juga melihat adakah pengaruh kepuasan kerja karyawan (job satisfction) terhadap kinerja karyawan (performance). Penelitian ini juga ingin mengetahui adakah pengaruh motivasi terhadap kinerja karyawan, pengaruh anggaran partisipatif pada kinerja karyawan melalui motivasi, dan adakah kepuasan kerja karyawan berpengaruh terhadap kinerja karyawan melalui motivasi.
\end{abstract}

Kata kunci: Anggaran Partisipatif, Kinerja Karyawan, Kepuasan Kerja, Motivasi 


\section{PENDAHULUAN}

Perguruan tinggi (Higher Education) merupakan salah satu organisasi publik yang berpengaruh positif terhadap segala bidang kehidupan, baik pada aspek kepribadian maupun perkembangan manusia. Untuk mewujudkan perguruan tinggi yang berkulitas, salah satu aspek yang harus ditingkatkan dan di kelola dengan baik adalah anggaran. Anggaran dapat dikatakan sebagai komponen penting dalam perencanaan perguruan tinggi yang berisikan rencana-rencana kerja serta mengindikasikan kegiatan guna mencapai tujuan organisasi. Penganggaran adalah proses atau metode untuk mempersembahkan kemudahan dalam menjalankan anggaran (Mardiasmo, 2006). Ketersediaan anggaran yang terbatas di Universitas Teuku Umar harus menjadi perhatian semua pihak dalam pengelolaannya. Pengelolaan secara partisipasi dianggap paling tepat karena penggunaan anggaran dapat dilakukan secara efektif dan efisien serta tepat sasaran dalam penggunaannya. Partisipasi anggaran merupakan kegiatan penyusunan anggaran dengan melibatkan pihak-pihak terkait dalam organisasi, agar hasil dari pengambilan keputusan tersebut dapat sesuai dengan kebutuhan organisasi. Bognaes (2009) dalam Edwin (2014) menjelaskan partisipasi anggaran memainkan peran penting dalam komitmen tujuan yang berdampak langsung terhadap kinerja pegawai. Ini akan sangat sulit dicapai apabila karyawan tidak menunjukkan minat dalam tugas yang mereka kerjakan. Untuk itu partisipasi anggaran sangat menentukan minat karyawan dalam bekerja.

Mangkunegara (2009) menjelaskan hasil kerja dapat dilihat secara kualitas maupun kuantitas dari pencapaian seorang pegawai ketika melakukan kewajibannya menurut tanggung jawab yang ditetapkan kepadanya. Salah satu yang mempengaruhi loyalitas karyawan dalam melakukan kinerjanya yaitu adanya rasa puas dari karyawan itu sendiri. Peningkatan kualitas pendidikan merupakan syarat mutlak da1am percepatan terwujudnya masyarakat yang cerdas yang didukung dengan kinerja dari karyawan sebagai penggerak dalam manajerial, dengan menghasilkan kinerja yang baik. Peran karyawan sangat penting dalam kesuksesan sebuah organisasi. Kinerja karyawan berarti produktivitas dan output karyawan sebagai hasil dari pengembangan karyawan, dan akhirnya akan mempengaruhi efektivitas organisasi (Hameed dan Waheed, 2011).
Handoko (2010) menyatakan "kepuasan kerja itu dapat terjadi dan dapat dilihat sesuai dengan emosi yang membahagiakan ataupun tidak membahagiakan, saat karyawan melihat tugas yang mereka kerjakan. Rasa puas dalam pekerjaan dicerminkan oleh perasaan karyawan untuk pekerjaannya. Hal ini dapat dilihat dari sikap positif karyawan akan pekerjaan serta segala sesuatu yang dijalani di tempat kerjanya”. Perilaku ini dicerminkan oleh prestasi kerja, kedisiplinan serta moralitas dalam bekerja.

Penelitian Stella (2013), Kusuma (2013), Budiman dkk (2014), Yusfaningrum (2005) mengatakan dalam penyusunan anggaran sistem partisipasi memiliki dampak positif terhadap kinerja. Demikian juga saat Laberto melakukan penelitian, ia menemukan bahwa penyusunan anggaran partisipatif memberikan pengaruh positif kepada kinerja manajerial, ia mengatakan semakin tinggi keterlibatan karyawan dalam penyusunan anggaran maka samakin tinggi kinerja karyawan yang akan dihasilkan.

\section{KAJIAN PUSTKA Partisipasi Anggaran}

Ditinjau dari segi etimologis, kata partisipasi bersumber dari bahasa Be1anda "participatie" atau dari bahasa 1nggris "Participation" (sukanto, 1983 dalam Safroni, 2013). Dalam bahasa latin yaitu "Participatio" yâng bersumber dari kata "Partipare" yang berarti turut serta, sehingga partisipasi mempunyai makna adanya kegiatan atau aktivitas. Dari Davis dan Newstrom (2004) kata partisipasi adalah keterlibatan menta1 dan emosional orangorang da1am situasi kelompok, serta mendorong mereka untuk memberikan suatu kontribusi demi tujuan kelompok, dan juga berbagai tanggung jawab dalam pencapaian tujuan.

Teori penetapan tujuan tujuan (goal setting theory) yang dikembangkan oleh Locke (1968) dalam Sinambela (2016) mengatakan bahwa hubungan antara tujuan yang ditetapkan yang diperoleh dari hasil kerja. Hoque dan Peter (2007) mengemukakan bahwa partisipsi penganggaran adalah proses dimana karyawan ikut berpartisipasi dalam memutuskan anggaran akhir dan memiliki pengaruh pada anggaran akhir tersebut. Partisipasi yang dimaksud menunjukkan adanya keterkaitan antara karyawan dengan atasannya dalam melakukan berbagai perencanaan serta mengambil keputusan yang menyangkut apa tujuan dari organisasi (Affes, 2012). Partisipasi anggaran dapat juga diartikan sebagai sarana bagi karyawan dalam mengajukan 
ide-ide serta masukan mengenai anggaran sehingga target yang disusun tidak terlalu menyulitkan para pelaksana anggaran yang mengetahui potensi dan hambatan dalam organisasi sehari-hari (Lau dan Tan, 2003).

Onsi dalam Safroni (2012) menjelaskan Partisipasi dalam penyusunan anggaran akan berdampak baik pada para pelaku anggaran yaitu 1ebih memahami masalah-masalah yang mungkin timbul saat pelaksanaan anggaran sehingga partisipasi da1am penyusunan anggaran dapat meningkatkan efisiensi. Manfaat manajemen partisiatif sebagai berikut:

a. Memungkinkan karyawan 1ebih mampu ketika terjadinya perubahan-perubahan dalam manajemen, serta turut berperan serta menjadi kunci penggerak untuk institusi dan memposisikan karyawan maupun manajer saat bersikap "change oriented"

b. Menciptakan suatu keterkaitan timbal balik antara manajer, bawahan serta serikat pekerja

c. Meningkatkan rasa memiliki karyawan maupun manajer pada institusi.

d. Menumbuhkan tingkat percaya diri terhadap organisasi

e. Mempermudah dalam megelola bawahan

f. Mempertinggi mutu komunikasi baik dari atasan maupun bawahan.

\section{Kinerja Karyawan}

Model Deming mengatakan bahwa proses manajemen kinerja diawali dengan penyusunan rencana awal, pelaksanaan, memantu jalannya proses kegiatan maupun hasil pelaksanaan, serta melakukan evaluasi atas berjalannya pelaksana pekerjaannya (Armstrong, 1998 dalam Sinambela, 2016). Kinerja mempunyai makna dan pengertian lebih luas, tidak hanya output dari pekerjaaan namun mengenai proses pekerjaan yang berlangsung. Onnes dan Viswesvaran (2000) dalam Jimoh (2008) menjelaskan bahwasanya kinerja adalah pekerjaan, tindakan serta output yang bisa diukur, semua tindakan dilakukan berkaitan dengan arah dan tujuan organisasi serta berkontribusi pada tujuan organisasi. Kinerja karyawan menurut Mahmudi (2005) merupakan sebuah ukuran yang biasanya digunakan dalam perbandingan hasil kinerja dan tanggung jawab yang diberikan oleh organisasi pada periode tertentu.

Argyris (1952) dalam Hasniasari (2014) menjelaskan bahwa peningkatan kinerja karyawan bisa terjadi jika karyawan diikutsertakan dalam proses penganggaran.

\section{Kepuasan Kerja}

Kepuasan kerja diartikan sebagai perasaan karyawan atas pekẹrjaan yang telah dilakukan oleh karyawan itu sendiri, dan berkaitan dengan faktorfaktor dari luar dirinya, baik kondisi kerja, hasi1 yang diperoleh maupun pekerjaan itu sendiri (Sinambela, 2016). Soetjipto dan Desiana (2006) menjelaskan bahwa kepuasan kerja adalah perasaan karyawan terhadap pekerjaannya baik secara keseluruhan maupun terhadap berbagai aspek da1am pekerjaannya sebagai hasil pengetahuan dan penilaian karyawan terhadap pekerjaan, yang pada akhirnya dapat mengarahkan karyawan pada tingkah laku tertentu. Kepuasan kerja dilihat dari rasa puas terhadap hasil pekerjaan yang dilakukan, rasa puas atas promosi, teman kerja, penyelia dan gaji (luthans, 2006). Sikap individu terhadap pekerjaan akan berbeda-beda tergantung dari seberapa kepuasan yang diperoleh dan dirasakan, semakin tinggi tingkat kepuasan maka semakin banyak aspek da1am pekerjaannya.

\section{Motivasi}

Motivasi berasal dari kata movere yang berarti dorongan. Motive atau dalam bahasa latin mengandung mengerahkan. Liang Gie (1992) dalam Sanuddin (2012) motive atau dorongan merupakan pemicu yang menjadi dasar seseorang dalam berbuat sesuatu pekerjaan. Motivasi membahas mengenai pengarahan sumber daya serta kemampuan karyawan guna melakukan pekerjaan secara maksimal dan untuk mencapai tujuan yang ditetapkan (Hasibuan, 2011). Menurut Wibowo (2011) serangkaian kegiatan pada sikap manusia dalam mencapai tujuannya. Walaupun sumber yang ada di dalam motivasi terdiri dari unsur yang mengarahkan, menjaga, membangkitkan, menunjuk, adanya tujuan dan terus-menerus.

Menurut Kadarisman (2012) pada hakikatnya tujuan pemberian motivasi kerja kepada pegawai adalah untuk:

a. Mengubah peri1aku karyawan sesuai dengan keinginan organisasi

b. Meningkatkan gairah dan semangat kerja

c. Meningkatkan disiplin kerja

d. Meningkatkan prestasi kerja

e. Meningkatkan rasa tanggung jawab

f. Meningkatkan produktvitas \& efisiensi

g. Menimbu1kan loyalitas pada organisasi

Menurut George \& Jones (2006) indikator motivasi kerja karyawan adalah (1) perilaku karyawan, (2) usaha karyawan, (3) kegigihan 
karyawan. Motivasi diartikan sebagai pendorong yang mampu melahirkan kegairahan bagi karyawan untuk bekerja secara efektif dan terintegrasi yang diperlihatkan dari tindakan dan bertujuan untuk mencapai tingkat kepuasan (Winardi, 2000 dalam Fariayana, 2012)

\section{Kerangka Konseptual Dan Hipotesis Penelitiąn}

Kerangka konseptual adalah sintesa mengenai hubungan antar variabel yang dirangkai dari beberapa teori yang sudah dijelaskan. Dari teoriteori yang sudah dijabarkan tersebut, selanjutnya dianalisiskan sesara krisis dan sistematis, sehingga menghasilkan sintesa tentang hubungan antar variabel yang diteliti. Sintesa tentang hubungan variabel tersebut, selanjutnya digunakan untuk merumuskan hipotesis (Sugiyono, 2010).

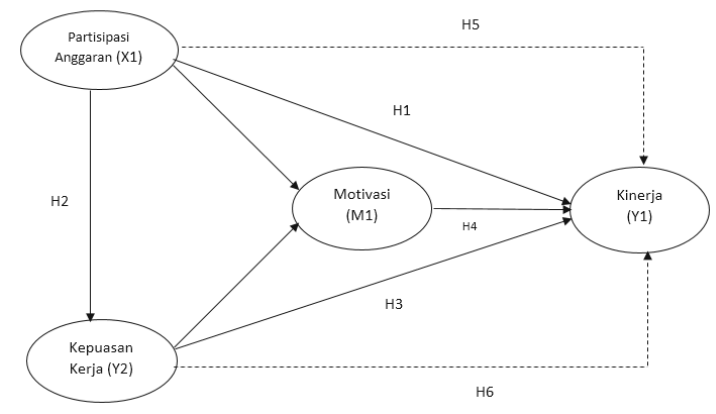

Gambar 1 Mode1 Pene1itian

\section{Partisipasi Terhadap Kinerja Karyawan}

Henry (2013) menjelaskan bahwa di dalam proses penganggaran di dalam manajemen terdapat hubungan antara program anggaran guna meningkatkan kinerja, keterkaitan proses anggaran dapat dilihat dalam program yang digunakan dalam penganggaran kinerja, serta dapat meningkatkan kinerja. Proses dalam menyusun anggaran memiliki pengaruh langsung pada perilaku manusia (Siegel dan Marconi, 1989) dalam (Safroni). Tujuan anggaran partisipatif untuk meningkatkan kinerja karyawan. Karena apabila tujuan dan dan perencanaan yang diatur berdasarkan sistem partisipatif disepakati, tentu karyawan akan mencapai tujuan dan standar yang ditetapkan dengan rasa tanggung jawab dan penuh keyakinan dalam mencapainya dikarenakan ikut terlibat dalam penyusunannya (Milani, 1975 dan Asriningati, 2006) dalam (Safroni, 2012). Selain itu didukung dari hasil penelitian Stella (2013) dan Fitrianti (2010), Kusuma (2013), Budiman dkk (2014), Yusfaningrum (2005), dan Carmmila Manica (2016) yang menunjukkan hasil bahwa terdapat pengaruh antara anggaran partisipatif terhadap kinerja karyawan.

$\mathrm{Hl}$ : Anggaran partisipatif berpengaruh positif dan signifikan terhadap kinerja karyawan

\section{Partisipasi Terhadap Kepuasan Kerja Karyawan.}

Para perancang penganggaran harus mempunyai alasan logis ketika menentukan besaran untuk menetapkan jumlah penerimaan dan pengeluaran, serta sistem informasi keuangan dalam pengendalian rutin, mencari solusi untuk setiap masalah dan melakukan tindakan. Adanya partisipasi semua elemen atau bagian dalam penyusunan anggaran akan menstimulus meningkatnya kepuasan kerja mereka. Siegel (1989) dalam Nengsy (2013) menjelaskan bahwasanya anggaran dapat berdampak langsung pada tindakan karyawan, terlebih pada karyawan yang menyusun dan menetapkan anggaran. Sesuai dengan hasil penelitian Nenngsy sari dan Agusti (2013), Sujanna (2013), Stella (2013), dan Wulandari menjelaskan bahwa anggaran partisipasif akan mempengaruhi kepuasan kerja secara positif dan signifikan.

$\mathrm{H} 2$ : Anggaran partisipastif berpengaruh positif dan signifikan terhadap kepuasan kerja karyawan

\section{Kepuasan Kerja Karyawan Terhadap Kinerja}

Greeberg dan Baron (2003) menjelaskan bahwa kepuasan kerja sebagai sikap negatif dan positif karyawan atas pekerjaan dan tindakan mereka. (Robbins 2006 dalam Kristianto 2010) karyawan yang mempunyai tingkat kepuasan kerja maksimal akan memperlihatkan sikap positif pada pekerjaannya, orang yang merasa tidak puas akan pekerjaannya maka akan memperlihatkan sikap negatif pada pekerjaannya. Handoko (2010) menjelaskan bahwa ketika karyawan memiliki kepuasan terhadap pekerjaannya maka dia akan memiliki semangat yang tinggi untuk bekerja untuk mencapai hasil kinerja yang maksimal. Penilaian kinerja merupakan metode kerja yang dilakukan oleh organisasi agar dapat menilai berapa besar kepuasan kerja terhadap kewajibannya dalam lingkungan kerja. (Hasibuan, 2011). Untuk meningkatkan kepuasan kerja karyawan, salah satu cara dapat dilakukannya penilaian kinerja. Dengan itu, karyawan tersebut akan terus berkeinginan meningkatkan kinerjanya (Nengsi dkk, 2013). Locke (1996) dalam Adiko Winnetouw (2008) menjelaskan bahwa kepuasan kerja adalah apa yang dirasakan oleh seseorang pekerja atas pekerjaan mereka, ha1 ini menunjukkan bahwa sejauh mana individu merasakan hasi1 yang sesuai 
dengan apa yang mereka harapkan dari suatu pekerjaannya sehingga nantinya akan secara langsung mempengaruhi kinerja karyawan. Seperti yang ditemukan oleh hasil penelitian Mahendra (2010), Mariam (2009), Nengsih dkk (2013), yaitu dampak dari kepuasan kerja terhadap kinerja. Penelitian yang ditunjukkan oleh Kristianto (2011), mengatakan bahwa kepuasan kerja yang dirasakan oleh karyawan mampu berpengaruh secara positif dan signifikan pada pekerjaan karyawan. Ketika tingkat kepuasan kerja tinggi, maka dengan sendirinya kinerja akan semakin tinggi. Sehingga dapat dikatakan bahwa kepuasan kerja sangat mempengaruhi kinerja.

H3: Terdapat pengaruh positif dan signifikan dari kepusan kerja terhadap kinerja karyawan

\section{Motivasi Terhadap Kinerja}

Motivasi sangat dibutuhkan dalam meningkatkan kinerja. Apabila kinerja karyawan meningkat maka akan meningkatkan pula kinerja institusi. Dapat disimpulkan bahwa, motivasi karyawan dapat mempengaruhi kinerja individu, kelompok maupun organisasi (Wibowo, 2016). Motivasi merupakan proses psikologi yang mengarahkan tindakan untuk mencapai tujuan atau goal-directed behavior (Kreitner dan Kinicki, 2001) dalam (Wibowo, 2016. Motivasi kerja merupakan sebuah kondisi pendorong atau penyebab bagi seseorang untuk melakukan sebuah kegiatan atau pekerjaan, yang dilakukan secara sadar (Bangun, 2012). Menurut Torang (2013) motivasi kerja adalah energi yang menggerakkan individu untuk berusaha mencapai tujuan yang diharapkan dalam melakukan pekerjaannya. Memperhatikan motivasi karyawaan adalah sebuah hal yang sangat penting karena motivasi tersebut merupakan motor penggerak bagi personal yang membuat mereka melakukan sesuatu. Hal ini diperkuat dari penelitian Iva (2016) yaitu ia menjelaskan motivasi kerja mempunyai dampak yang signifikan pada kinerja karyawan, ini memperjelas bahwa motivasi kerja dapat meningkatkan kinerja karyawan.

$\mathrm{H} 4$ : Adanya pengaruh dari variabel motivasi dengan positif dan signifikan terhadap variabel kinerja karyawan

\section{Partisipasi Anggaran Terhadap Kinerja Karyawan Melalui Motivasi}

Perasaan dihargai dan dilibatkan dalam penyusunan anggaran akan menimbulkan motivasi dari dalam diri untuk menyelesaikan tugasnya dengan lebih baik. Sehingga dengan adanya motif yang tinggi dari manajer dalam menyelesaikan tugasnya maka diharapkan akan meningkatkan kinerja manajerial. Keterkaitan antara motivasi terhadap hubungan partisipatif anggaran dengan kinerja telah banyak diteliti oleh peneliti terdahulu. Poerwati (2002), Ghozali dan Adiputra (2002) mengemukakan bahwa anggaran partisipatif memiliki hasil secara positif terhadap kinerja manajerial menggunakan motivasi kerja sebagai variabel intervening. Penelitian yang dilakukan oleh Sembiring (2008) juga mendapatkan hubungn positif serta signifikan dari motivasi terhadap kinerja manajeria1, dengan motivasi sebagai variabe 1 intervening. Hal itu juga diperkuat oleh oleh penelitian Suharto dan Halim (2015) serta penelitian Kusumawati (2012) menguraikan peran partisipasi dalam proses penetapan anggaran melalui motivasi memiliki terhadap kinerja.

H5: Adanya pengaruh anggaran partisipatif terhadap kinerja karyawan melalui motivasi secara positif dan signifikan.

\section{Kepuasan kerja Karyawan Terhadap Kinerja Melalui Motivasi}

George \& Jones (2006) menyebutkan bahwa motivasi kerja diukur dengan perilaku karyawan, usaha karyawan, serta kegigihan karyawan. Di sisi 1ain kinerja meliputi aspek kuantitas , kua1itas, efektivitas, ketepatan waktu, dan kemandirian (Robbins, 2006). Dari pendekatan tersebut maka dapat ditarik kesimpulan jika motivasi kerja karyawan meningkat semakin baik, pastinya kinerja karyawan ikut serta semakin meningkat baik itu yang berkaitan dengan kualitas, kuantitas, ketepatan waktu, efektivitas maupun kemandirian. Adanya motivasi yang tinggi dari karyawan akan menggerakkan karyawan tersebut untuk usahanya dalam mencapai tujuan mencapai hasil yang diinginkan. (Suharto dan Cahyo, 2005), Hasil penelitian ini mendukung penelitian yang dilakukan oleh Ganta (2014), dimiliki perilaku karyawan berkaitan dengan motivasi kerja, dan perusahaan harus mengetahui cara dan strategi dalam memotivasi pegawainya untuk memicu kinerja pegawai. Penelitian Wahyuddin dan Prasetyo (2003) juga menjawab bahwa motivasi adalah faktor yang paling banyak mempengaruhi kinerja karyawan. Penelitian yang dilakukan oleh Tjiong (2018) memperoleh hasil bahwa koefisien estimasi yang dihasilkan bernilai positif yang memiliki arti yaitu apabila kepuasan kerja meningkat, maka semakin meningkat pula kinerja karyawan secara nyata.

H6: Terdapat pengaruh yang positif dan signifikan dari variabel partisipasi anggaran terhadap kinerja karyawan melalui motivasi. 


\section{METODE PENELITIAN}

Peneliti melakukan penelitian ini pada sebuah perguruan tinggi negeri baru Universitas Teuku Umar yang berlokasi di Aceh Barat, Indonesia. Penelitian yang dilakukan ini menggunakan metode kuantitatif deskriptif untuk melihat dan mejelaskan hubungan antara variabe1variabel melalui hipotesa juga mengdeskripsikan situasi dan kondisi yang ada pada subyek yang merupakan objek penelitian. Penelitian ini menggunakan Smart Partial Least Squart (Smart PLS) 3.2.8 dalam menganalisis data, metode ini dinggap sesuai dalam mengestimasi path model. Penelitian ini memiliki beberapa konstruk laten dengan beberapa indikator sehingga sangat membantu untuk mengetahui nilai dan memprediksi dari variabel laten. Untuk melakukan evaluasi menggunakan Smart PLS, maka dilakukan evaluasi outer model dan evaluasi inner model.

\section{Popu1asi dan Sampe1}

Populasi pada penelitian ini ada1ah seluruh pejabat strukural dan tenaga kependidikan yang ada di Universitas Teuku Umar berjum1ah 212 orang. Metode pegambilan sampe 1 menggunakan desain pengambilan sampel acak berstrata proporsional, dilakukan sampling ini apabila anggota populasinya tidak sejenis (heterogen). Dalam penentuan sampel terlebih dahulu tentukan rumus populasi sudah diketahui, yaitu menggunakan rumus dari Taro Yamane atau Slovin. Dengan menggunakan formula pengambilan yang telah ditentukan, banyaknya sampel pada penelitian ini yaitu 66 orang terdiri dari dekan, wakil dekan, kepala UPT dan LPPM, KTU, Kabag, Kasubbag, dan staf.

Penelitian ini menggunakan metode kuantitatif deskriptif guna melihat dan menjelaskan hubungan antara variabe1-variabel melalui hipotesa serta menjelaskan berbagai kondisi dan situasi yang timbul pada subyek yang menjadi objek.

\section{Instrumen Pengukuran}

Ada empat variabel yang diukur pada penelitian ini yaitu variabel partisipasi anggaran, variabe1 kinnerja, variabel kepuasan kerja serta variabe1 motivasi. Variabel partisipasi anggaran diukur menggunakan 6 indikator menggunakan 5 poin skala likert, adapun indikatornya yaitu keikutsertaan ketika proses penyusunan anggaran, kepuasan dalam penyusunan anggaran, kebutuhan memberikan pendapat, kerelaan dalam memberikan pendapat, besarnya pengaruh terhadap penetapan anggaran dan seberapa seringnya atasan meminta pendapat atau usulan saat anggaran disusun.

Variabel kinerja diukur dengan menggunakan 7 indikator, menggunakan 5 poin skala likert. Adapun indikator yang digunakan adalah pencapaian target kinerja kegiatan dari suatu program, ketepatan dan kesesuaian hasil, tingkat pencapaian program, dampak hasi1 kegiatan terhadap kehidupan masyarakat, kesesuaian realisasi anggaran dengan penetapan anggaran, pencapaian efisiensi operasional dan moral perilaku karyawan.

Pengukuran variabel kepuasan kerja dilakukan menggunakan 5 indikator, menggunakan 5 poin skala likert. 5 indikator itu yaitu kesempatan promosi, pekerjaan itu sendiri, gaji, pengawasan dan rekan kerja.

Variabe1 mofivasi kerja diukur dengan menggunakan 3 indikator, menggunakan 5 poin skala likert. Adapun 3 indikator tersebut ada1ah perilaku karyawan, usaha karyawan dan kegigihan karyawan.

\section{Uji Validitas dan Reliabilitas}

Uji validits digunakan untuk mengukur keabsahan suatu kuesioner. Menggunakan nilai signifikansi sebesar $(\alpha)$ 5\% yaitu apabila T-hitung $>\mathrm{T}$-tabe 1 maka hasil hasil pengujian dapat dinyatakan valid, namun jika t-hitung $\geq \mathrm{t}$-tabe 1 maka hasil pengujian dinyatakan tidak valid.

Sedangkan uji reliabilitas untuk mengukur konsistensi alat ukur da1am mengukur konsistensi responden dalam menjawab kuesioner. Reliabilitas dapat diukur dengan melihat nilai Cronbach's Alpha dimana semua konstruk harus $>$ 0,7 dan hasil pemeriksaan Composite Relibility berdasarkan convergent dengan melihat nilai Average Variance Extracted (AVE) $\geq 0,5$. Pengujian reliabilitas konstruk selanjutnya adalah dengan mengevaluasi discriminant validity yang meliputi cross loding dengan melakukan perbandingan antara nilai akar AVE dengan korelasi antar konstruk.

\section{HASIL DAN PEMBAHASAN Ana1isis Mode1 Pengukuran}

Evaluasi mode1 pengukuran dilakukan guna mengevaluasi antara konstruk dengan indikator masing-masing dari konstruk, dibagi dalam dua tahap yaitu convergen validitas dan discriminance validity. Convergent validity untuk melihata hasil validitas indikator, dapat dievaluasi melalui tiga tahap, yaitu loading factor $(L F), T$-statistik dan $P$ Value. Sedangkan discriminant validity untuk 
melihat reliabilitas konstruk, dapat dievaluasi melalui cross loading, cronbach alpha, composite realibility, AVE dan perbandingan akar AVE.

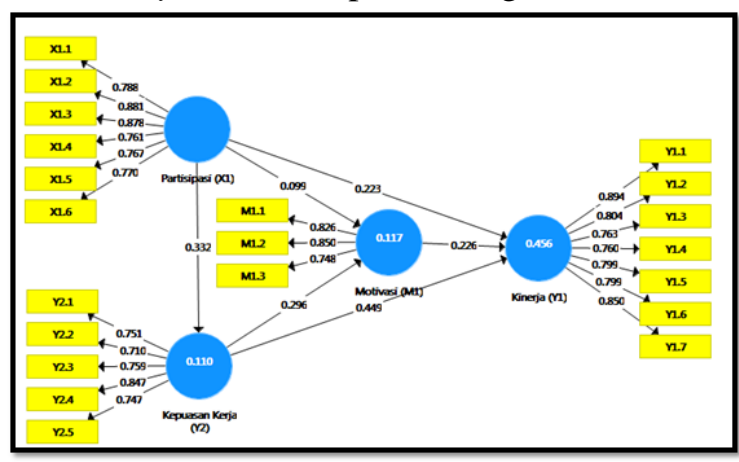

Gambar 2. Hasil PLS Model Pengukuran

\section{A. Convergent Validity}

Mode1 pengukuran untuk uji validitas dan reliabilitas koefisien determinasi mode1 dan koefisien jalur mode1 persamaan, dapat dilihat pada gambar 1 di bawah ini.

Tabel 1. Hasil PLS untuk Convergent Validity

\begin{tabular}{|c|c|c|c|}
\hline Variabel & Indikator & $\begin{array}{l}\text { Loading } \\
\text { Factor }\end{array}$ & Keterangan \\
\hline \multirow[t]{6}{*}{$\mathrm{X} 1$} & $\mathrm{X} 1.1$ & 0,788 & Valid \\
\hline & $\mathrm{X} 1.2$ & 0,881 & Valid \\
\hline & $\mathrm{X} 1.3$ & 0,878 & Valid \\
\hline & X1.4 & 0761 & Valid \\
\hline & $X 1.5$ & 0,767 & Valid \\
\hline & X1.6 & 0,770 & Valid \\
\hline \multirow[t]{7}{*}{ Y1 } & Y1.1 & 0,894 & Valid \\
\hline & Y1.2 & 0,804 & Valid \\
\hline & Y 1.3 & 0,763 & Valid \\
\hline & Y1.4 & 0,760 & Valid \\
\hline & Y1.5 & 0,799 & Valid \\
\hline & Y1.6 & 0,799 & Valid \\
\hline & Y1.7 & 0,850 & Valid \\
\hline \multirow[t]{5}{*}{$\mathrm{Y} 2$} & Y2.1 & 0,751 & Valid \\
\hline & Y 2.2 & 0,710 & Valid \\
\hline & Y2.3 & 0,759 & Valid \\
\hline & Y2.4 & 0,847 & Valid \\
\hline & Y2.5 & 0,747 & Valid \\
\hline \multirow[t]{3}{*}{ M1 } & M1.1 & 0,826 & Valid \\
\hline & M1.2 & 0,850 & Valid \\
\hline & M1.3 & 0,748 & Valid \\
\hline
\end{tabular}

Dari tabel di atas terlihat semua nilai outer loading dalam pengukuran tiap variabel penelitian memiliki outer loading di atas 0.7 telah terpenuhi, dengan demikian seluruh indikator sebagai konstruk keempat variabel penelitian telah valid konvergen.
Tabel 2. Hasil Pengujian Convergent Validity

\begin{tabular}{|c|c|c|}
\hline Variabel & $\begin{array}{c}\mathbf{T} \\
\text { Statistik }\end{array}$ & $\begin{array}{c}\mathbf{P} \\
\text { Value }\end{array}$ \\
\hline $\begin{array}{l}\text { Partisipasi } \\
\text { Anggaran } \\
(\mathrm{X} 1) \rightarrow \text { Kinerja (Y1) }\end{array}$ & 2,045 & 0,041 \\
\hline $\begin{array}{ll}\text { Partisipasi } & \\
\text { Anggaran } & \text { (X1) } \\
\rightarrow \text { Kepuasan } & \text { Kerja } \\
(\mathrm{Y} 2) & \end{array}$ & 3,393 & 0,001 \\
\hline $\begin{array}{l}\text { Kepuasan } \quad \text { Kerja } \\
(\mathrm{Y} 2) \rightarrow \text { Kinerja (Y2) }\end{array}$ & 4,544 & 0,000 \\
\hline $\begin{array}{l}\text { Motivasi } \\
(\mathrm{M} 1) \rightarrow \text { Kinerja (Y1) }\end{array}$ & 1,788 & 0,073 \\
\hline
\end{tabular}

\section{B. Discriminant Validity}

Pengujian Discriminan Validity dilakukan untuk melihat reliabilitas konstruk, yaitu dengan membuktikan apakah indikator pada suatu konstruk mempunyai loading faktor dengan konstruk yang 1ain. Reliabilitas konstruk dapat dievaluasi melalui nilai cross loading, cronbanch's Alpha, composite reliability, AVE dan perbandingan akar AVE. Menggunakan kriteria Fornell Lorcker untuk melakukan validitas diskriminan, sesuai kriteria AVE pada variabe1 laten diharuskan 1ebih tinggi dari R2 yang ada pada variabel 1aten lainnya.

\section{Tabel 3. Hasil Cross Loading Discriminant Validity}

\begin{tabular}{ccccc}
\hline Indiktor & Y2 & Y1 & M1 & X1 \\
\hline M1.1 & 0,405 & 0,371 & $\mathbf{0 , 8 2 6}$ & 0,132 \\
M1.2 & 0,102 & 0,355 & $\mathbf{0 , 8 5 0}$ & 0,234 \\
M1.3 & 0,167 & 0,264 & $\mathbf{0 , 7 4 8}$ & 0,107 \\
X1.1 & 0,167 & 0,192 & 0,124 & $\mathbf{0 , 7 8 8}$ \\
X1.2 & 0,210 & 0,357 & 0,185 & $\mathbf{0 , 8 8 1}$ \\
X1.3 & 0,341 & 0,433 & 0,289 & $\mathbf{0 , 8 7 8}$ \\
X1.4 & 0,351 & 0,368 & 0,136 & $\mathbf{0 , 7 6 1}$ \\
X1.5 & 0,147 & 0,335 & 0,157 & $\mathbf{0 7 6 7}$ \\
X1.6 & 0,322 & 0,235 & $-0,023$ & $\mathbf{0 , 7 7 0}$ \\
Y1.1 & 0,510 & $\mathbf{0 , 8 9 4}$ & 0,415 & 0,365 \\
Y1.2 & 0,465 & $\mathbf{0 , 8 0 4}$ & 0,198 & 0,373 \\
Y1.3 & 0,312 & $\mathbf{0 , 7 6 3}$ & 0,335 & 0,295 \\
Y1.4 & 0,604 & $\mathbf{0 , 7 6 0}$ & 0,256 & 0,526 \\
Y1.5 & 0,333 & $\mathbf{0 , 7 9 9}$ & 0,385 & 0,185 \\
Y1.6 & 0,574 & $\mathbf{0 , 7 9 9}$ & 0,366 & 0,238 \\
Y1.7 & 0,481 & $\mathbf{0 , 8 5 0}$ & 0,423 & 0,306 \\
Y2.1 & $\mathbf{0 , 7 5 1}$ & 0,338 & 0,351 & 0,153 \\
Y2.2 & $\mathbf{0 , 7 1 0}$ & 0,396 & 0,248 & 0,070 \\
Y2.3 & $\mathbf{0 , 7 5 9}$ & 0,344 & 0,165 & 0,469 \\
Y2.4 & $\mathbf{0 , 8 4 7}$ & 0,636 & 0,361 & 0,355 \\
Y2.5 & $\mathbf{0 , 7 4 7}$ & 0,489 & 0,083 & 0,127 \\
\hline & & & &
\end{tabular}

Dari tabe1 3 di atas menunjukkan ni1ai cross 1oading juga menunjukkan adanya discriminant 
validity yang baik karena mempunyai nilai kore1asi indikator terhadap konstruk 1ebih tinggi jika dibandingkan nilai korelasi indikafor dengan konstruk lainnya.

Tabel 4 . Hasil Discriminat Validity

\begin{tabular}{lcc}
\hline Variabel & $\begin{array}{c}\text { Composite } \\
\text { Reliability }\end{array}$ & $\begin{array}{l}\text { Cronbanc's } \\
\text { Alpha }\end{array}$ \\
\hline Partisipasi & 0,919 & 0,896 \\
Anggaran & & \\
Kinerja & 0,931 & 0,913 \\
Kepuasan Kerja & 0,874 & 0,825 \\
Motivasi & 0,855 & 0,749 \\
\hline
\end{tabular}

Konstruk dinyatakan reliabe1 jika memiliki nilai composite reliability di atas 0.70 dan cronbach's alpha di afas 0.60. Dari hasil output SmartPLS di atas, semua konstruk memiliki nilai composite reliability di atas 0.70 dan cronbach's a1pha di atas 0,60. Jadi konstruk memiliki reliabilitas yang baik, sehingga dapat disimpulkan seluruh indikator memang menjadi pengukur konstruknya masing-masing.

Tabel 5. Hasil Pengujian AVE

\begin{tabular}{cccc}
\hline Variabel & AVE & $\begin{array}{c}\text { Akar } \\
\text { AVE }\end{array}$ & Ket \\
\hline$(\mathrm{X} 1) \rightarrow(\mathrm{Y} 1)$ & 0,656 & 0,81 & Reliabel \\
$(\mathrm{X} 1) \rightarrow(\mathrm{Y} 2)$ & 0,658 & 0,811 & Reliabel \\
& & & Reliabel \\
$(\mathrm{Y} 2) \rightarrow(\mathrm{Y} 2)$ & 0,583 & 0,764 & \\
& & & \\
$(\mathrm{M} 1) \rightarrow(\mathrm{Y} 1)$ & 0,664 & 0,815 & Reliabel \\
\hline
\end{tabular}

Output AVE memperlihatkan nilai lebih dari 0,50. Variabel partisipasi memiliki nili AVE 0.656, variabel kinerja memperoleh nilai AVE 0.6658, variabel kepuasan kerja memiliki nilai AVE 0.583 dan variabel motivasi nilai AVE 0,664. Dengan demikian dikatakan reliabel.

\section{Mode1 Struktural (Inner Mode1)}

Inner mode1 menggambarkan hubungan antar variabe 1 1aten berdsarkan pada subtantif theory. Mode1 struktura1 dilakukan untuk melihat hubungan antar konstruk seperti yang dihipotesiskan dalam penelitian ini. Da1am PLS dievaluasi dengan melihat $\mathrm{R}$-square untuk variabe 1 dependent dan nilai koefisien jalur untuk variabe1 independen yang kemudian dinilai signifikansinya berdasarkan nilai t-statistik setiap peth. Sedangkan untuk melihat nilai koefisien jalur untuk variabel intervening, dapat dilihat dari hasil Specifik
Indirect Effect. Adapun mode1 struktura1 penelitian ini dapat dilihat pada gambar berikut:

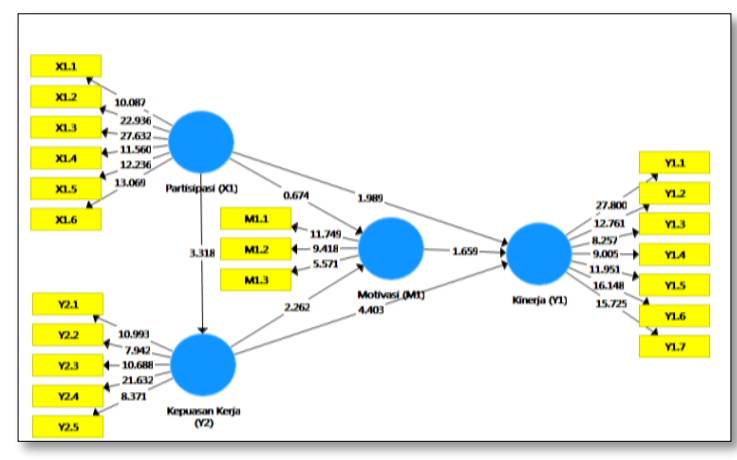

Gambar 3. Tampilan Output Model
Struktura1

Tabel 6. R-Square

\begin{tabular}{l|c}
\hline \multicolumn{1}{c|}{ Variabel } & R-Square \\
\hline Partisipasi Anggaran (X1) & \\
Kinerja (Y1) & 0,456 \\
Kepuasan Kerja (Y2) & 0,110 \\
Motivasi Kerja (M1) & 0,117 \\
\hline
\end{tabular}

Hasil tabel 6 menunjukkan nilai R-Square sebesar $0.456,0,110$, dan O.117 untuk variabe1 endogen dalam mode1 struktura1 mengidentifikasikan bahwa mode1 baik.

Tabel 7. Path Coeffients (Mean,STDEV,t-Value)

\begin{tabular}{lcccc}
\hline Variabel & $\begin{array}{c}\text { Originl } \\
\text { Sample } \\
\text { Estimate }\end{array}$ & $\begin{array}{c}\text { Koefisien } \\
\text { Jalur }\end{array}$ & T-Statistik & $\begin{array}{l}\text { P- } \\
\text { Value }\end{array}$ \\
\hline $\mathrm{X} 1 \rightarrow \mathrm{Y} 1$ & 0,223 & 1,989 & 2,045 & 0,041 \\
$\mathrm{X} 1 \rightarrow \mathrm{Y} 2$ & 0,332 & 3,318 & 3,393 & 0,001 \\
$\mathrm{Y} 2 \rightarrow \mathrm{Y} 1$ & 0,449 & 4,403 & 4,544 & 0,000 \\
$\mathrm{M} 1 \rightarrow \mathrm{Y} 1$ & 0,226 & 1,659 & 1,798 & 0,073 \\
\hline
\end{tabular}

Dari hasil pengolahan dengan PLS, dapat diketahui bahwa Partisipasi Anggaran (X1) terhadap Kinerja karyawan (Y1) menunjukkan nilai koefisien jalur sebesar 1,989 dan t statistik 2,045 lebih besar dari $\mathrm{t}$ tabe 1 1,670 ( $\mathrm{t}$ statistic > t tabel), dengan demikian variabel partisipasi anggaran memiliki nilai yang positif dan signifikan terhadap variabe1 kinerja. Hasil ini mendukung H1 yaitu berbunyi bahwa anggaran partisipatif berpengaruh secara positif serta secara signifikan terhadap variabel kinerja karyawan.

Hasil dari analisis yang dilakukan menemukan variabel anggaran partisipatif terhadap variabel kepuasan kerja dengan koefisien jalur 3,318, $\mathrm{t}$ statistik 3,393 $>\mathrm{t}$ table $1,670(\mathrm{t}$ statistik $>\mathrm{t}$ 
tabel), Artinya variabel partisipasi memiliki pengaruh positif dan signifikan pada variabel kepuasan kerja. Hal ini mendukung $\mathrm{H} 2$ yang berbunyi terdapat pengaruh positif dan signifikan dari partisipasi anggaran terhadap kepuasan kerja karyawan.

Hasil analisis pada variabel kepuasan kerja terhadap kinerja menemukan hasil koefisien sebesar 4,403, t-statistik 4,544 lebih besar dari t tabel 1,670 (t statistik > t tabel), maka diperoleh variabel kepuasan kerja berpengaruh positif dan signifikan terhadap variabel kinerja. Sehingga analisis yang digunakan mendukung $\mathrm{H} 3$ yaitu terdapat pengaruh antar kepuasan kerja terhadap kinerja karyawan secara positif dan signifikan.

Hasil analisis variabel motivasi terhadap variabel kinerja menunjukkan nilai koefisien sebesar 1,659 dengan t statistik 1,798 lebih besar dari t table 1,670 ( $\mathrm{t}$ statistik > t tabel), seperti yang dijelaskan di atas variabel motivasi berpengaruh positif dan signifikan pada variabel kinerja. Artinya $\mathrm{H} 4$ yaitu motivasi kerja berpengaruh positif dan signifikansi terhadap kinerja karyawan sesuai dengan hasil temuan analisis.

Tabel 8. Specifik Indirect Effect

\begin{tabular}{lcccc}
\hline Variabel & $\begin{array}{c}\text { Originl } \\
\text { Sample } \\
\text { Estimate }\end{array}$ & $\begin{array}{c}\text { Koefisien } \\
\text { Jalur }\end{array}$ & T-Statistik & P-Value \\
\hline $\begin{array}{l}\mathrm{X} 1 \rightarrow \mathrm{M} 1 \\
\rightarrow \mathrm{Y} 1\end{array}$ & 0,223 & 0,027 & 0,042 & 0,595 \\
$\begin{array}{l}\mathrm{Y} 2 \rightarrow \mathrm{M} 1 \\
\rightarrow \mathrm{Y} 1\end{array}$ & 0,067 & 0,075 & 0,056 & 0,236 \\
\hline
\end{tabular}

Dari tabel 8 yaitu hasil analisis dari Spesifik indirect effect dapat dilihat bahwa variabel partisipasi terhadap variabel kinerja melalui variabel motivasi dapat dilihat pertama nilai koefisien jalur dari partisipasi pada motivasi adalah 0.674 , nilai koefisien motivasi pada variabel kinerja nilai koefisien sebesar 1,659, dari ke dua nilai koefisien tersebut memiliki nilai positif, dengan $\mathrm{t}$ statistik 0,532 1ebih keci1 dari $\mathrm{t}$ tabe1 1,670 (t-statistik<t-tabe1), maka dikatakan variabel partisipasi berdampak terhadap variabel kinerja dengan variabel motivasi sebagai variabel perantara mempunyai nilai positif namun tidak signifikan. Hasil tersebut menolak H5 yang berbunyi bahwa anggaran partisipatif berpengaruh positif dan signifikan terhadap kepuasan kerja karyawan melalui motivasi.

Analisis yang dilakukan menemukan hasil variabel kepuasan kerja berpengaruh pada variabe1 kinerja melalui variabel motivasi dapat dilihat pertama yaitu nilai koefisien jalur variabel kepuasan kerja terhadap motivasi karyawan sebesar 2.262, sedangkan koefisien jalur variabel motivasi pada kinerja dengan koefisien jalur 1,659, dari ke dua nilai koefisien tersebut memiliki nilai positif, dengan t statistik 1,187 1ebih keci1 dari $\mathrm{t}$ tabe1 1,670 ( $\mathrm{t}$ statistik < t tabe1), sehingga variabel kepuasan kerja ditemukan berdampak terhadap variabel kinerja melalui variabel motivasi mempunyai nilai positif namun tidak signifikan. Hasil tersebut menolak H6 yang berbunyi kepuasan kerja karyawan berpengaruh secara positif dan signifikan pada variabel kepuasan kerja pegawai.

\section{KESIMPULAN DAN SARAN Kesimpulan}

Diperoleh temuan positif dan signifikan dari partisipasi penyusunan anggaran yang berpengaruh jelas pada kinerja karyawan. Hal ini terlihat pada hasil koefisien jalur 0,417 untuk memperlihatkan signifikansi pengaruh sebesar 3,817 lebih besar dari t-tabel yaitu 1.670 (t statistik > t tabel), artinya semakin tinggi karyawan ikut berperan sesuai dengan posisinya masing-masing saat proses penetapan anggaran, maka semakin meningkat pula hasil kinerja karyawan.

Ditemukan adanya pengaruh positif dan signifikan dari anggaran partisipatif ketika menyusun anggaran terhadap kepuasan kerja pegawai. Anggaran partisipatif berdampak dan berpengaruh positif dan signifikan pada kepuasan kerja pegawai (tendik). Karyawan (tendik) merasa puas ketika turut dilibatkan, memahami dan dipahami apa yang dibutuhkan oleh karyawan (tendik). Hal ini dapat dilihat pada nilai koefisien jalur 0,332 yang memperlihatkan signifikansi hubungan 3,288 lebih besar dari t-tabel 1,670 (t statistik > t tabel). Semakin tinggi karyawan ikut partisipasi, maka akan tinggi pula tingkat kepuasan kerja karyawan tersebut.

Adanya pengaruh positif dan signifikan dari kepuasan kerja kepada kinerja pegawai. Ini diperlihatkan pada koefisien jalur 0,516 serta memperlihatkan signifikansi pengaruh 5,620 yaitu lebih besar dari t-tabel 1.670 (t-statistik > t-tabel). Apabila karyawan merasa semakin puas ketika dalam pekerjaannya, dapat dipastikan kinerja yang dilakukan juga akan ikut meningkat.

Adanya pengaruh positif dan signifikan yang ditunjukkan dari variabel motivasi kerja terhadap kinerja karyawan. Ini ditunjukkn oleh koefisien jalur yaitu 0.226 dan $T$ Statistics (|O/STERR $\mid)$ untuk menunjukkan signifikansi 
pengaruh yaitu 1.688 lebih besar dari t tabel 1,670 (t statistik > t tabel).

Terdapat hubungan yang mempengaruhi anggaran partisipatif terhadap kinerja karyawan dengan melewati variabel motivasi sebagai variabel antara. Dari hasil pengujian specifik indirect effect diperoleh nilai original sample estimate sebesar 0,023 dengan nilai t-statistik $0,532<1,670$ t-tabel, serta memiliki nilai signifikansi (P Value) sebesar 0,595 > 0,05 yang dilihat dari hasil spesifik indirect effects yakni variabel partisipasi anggaran ketika melewati variabel motivasi sebagai variabel perantara yang menuju ke variabel kinerja maka diperoleh hasil yang positif tetapi tidak signifikan . Partisipasi anggaran dipengaruhi oleh faktor motivasi, motivasi tersebut berupa adanya keinginan untuk memiliki sistem kerja yang jelas, mulai dari proses perencanaan, pelaksanaan dan hasil yang ingin dicapai. Hal ini dilakukan karena adanya harapan agar Universitas Teuku Umar mampu bersaing dengan universitas maju lainnya.

Ditemukan bahwa kepuasan kerja memiliki pengaruh positif terhadap kinerja karyawan, namun ketika melewati motivasi sebagai variabel perantara maka ditemukan hasil yang tidak signifikan . Berdasarkan hasil pengujian memperoleh nilai original sample estimate sebesar 0,067 dengan nilai t-statistik 1,187 > 1,670 t-tabel, serta memiliki nilai signifikansi ( $P$ Value) sebesar $0,236>0,05$ yang dilihat dari hasil spesifik indirect effects yang berarti variabel kepuasan kerja memiliki pengaruh yang positif tetapi tidak signifikan terhadap variabel kinerja karyawan yang dilalui oleh variabel motivasi. Maksudnya motivasi tidak menjadi faktor penyebab yang dapat berpengaruh antara partisipasi anggaran kepada kinerja karyawan.

\section{Saran}

Untuk mengoptimalkan partisipasi anggaran sebaiknya Universitas Teuku Umar mempertahankan kualitas kinerja para pegawai (tendik) dalam penyusunan anggaran dengan cara selalu me1akukan komunikasi dengan baik antara atasan dan bawahan dalam melakukan penyusunan anggaran sehingga pencapaian anggaran dapat terealisasi dengan baik. Universitas Teuku Umar harus memiliki data internal yang akurat mengenai catatan hasil kinerja dari para karyawan, yang dapat digunakan sebagai bahan evaluasi dan perbaikan untuk masa yang akan datang yang berkaitan dengan penganggaran.

Partisipasi tendik dalam penyusunan anggaran telah memberikan pengaruh positif dan signifikan pada peningkatan kepuasan kerja. Namun dibutuhkan adanya Standar Operasional Prosedur partisipatif yang menjadi dasar dalam tahapan proses anggaran. Standar operasional prosedur dalam kegiatan penganggaran harus disosialisasikan dan diketahui oleh semua unit kerja dan para karyawan, sehingga kesalahan dalam proses penganggaran dapat diketahui dimana titik permasalahannya, sehingga tidak terjadi saling menyalahkan antar bagian.

Kepuasan kerja berpengaruh terhadap kinerja di Universitas Teuku Umar disebabkan oleh beberapa faktor diantaranya besarnya jumlah anggaran yang disetujui sesuai dengan permintaan, baik jumlah anggaran mengenai program kegiatan secara umum maupun personal. Universitas semestinya terus meningkatkan kepuasan kerja karyawan sebagai pendorong dalam memperoleh hasil kinerja karyawan, universitas harus merancang program-program baru yang mampu meningkatkan rasa puas karyawan.

Motivasi ditemukan sebagai sesuatu yang sangat mempengaruhi dalam peningkatan kinerja karyawan. Motivasi bisa datang dari berbagai arah sesuai perkembangan kebutuhan. Untuk itu Universitas Teuku Umar harus mampu melihat perubahan kebutuhan para karyawannya. Salah satu cara adalah menggunakan kuesioner secara bertahap untuk mengevaluasi apa yang menjadi kendala serta motif apa yang mampu meningkatkan kinerja para karyawan.

\section{DAFTAR PUSTAKA}

Owushu, Eric Edwin. Dwomoh, Gabriel. Collins, Mintah. (2014). Assessing the Relationship between Budget Participation and Employees' Performance of Public Universities in Ghana: a Case of University of Education. International Journal of Academic Research in Accounting Finance and Management Sciences (IJAR AFMS). Vol. 4 No. 1, hal: 85-95.

Hasniasari Rahmia, \& Mahfud Sholihin. (2014). Analisis Hubungan Penganggaran Partisipatif dan Kinerja: Pengujian Efek Mediasi Keadilan Persepsian dan Komitmen pada Lembaga Hukum Sektor Publik di Indonesia. Jurnal Akuntansi dan Keuangan, Vol. 16 No. 1, hal: 23-32.

Kristianto, Dian. (2011). Pengaruh Kepuasan Kerja Terhadap Kinerja Karyawan dengan Komitmen Organisasi Sebagai Variabel Intervening.Jurnal Bisnis Strategi, Vol. 20, No. 2 hal: $165-175$ 
Hameed, A., dan Waheed, A. (2011). Employee Development and its affect on employee Performance a Conceptual Framework. International of Business and Social Science. Vol. 13, No. 2, hal: 224-230

Affes, H., \& Bouaziz, Z. (2012). "The Impact of the Strategy in Determining Transfer Prices: Case of the Tunisian Companies (electronic version)". Global Journal of Management and Business, 12(5) 11.

Osama, Mah'h. (2013). The Impact of Budgetary Participation on Mnagerial Performance: Evidence from Jordania University Executive. Journal of Applied Finance \& Banking. Vol. 3, No. 3, hal: 133-156.

Safroni, Lazdzi. (2012). Manajemen dan Reformasi Pelayanan Publik. Yogyakarta: Aditya Media Publishing.

Hasibuan, Malayu SP. (2011). Manajemen Sumber Daya Manusia. Cetakan ke-15. Jakaarta: Bumi Aksara

Fariyana Kusumawati \& M. Gus Salim. (2012). Hubungan Partisipasi Penyusunan Anggaran dengan Kinerja Pengelolaan Keuangan Daerah: Kepuasan Kerja dan Motivasi sebagai Variabel Pemoderasi. Infestasi. Vol. 8 No. 2, hal: 209-218.

Sinambela, Lijan Poltak. (2016). Manajemen Sumber Daya Manusia. Jakarta: Bumi Aksara

George, J. M., dan Jones, GR. (2006). Contemporary Management: Creating Value in Organization, 4st edition, 353. New York: McGraw Hill

Haryono, Siswoyo. (2017). Metode SEM untuk Penelitian Manajemen AMOS Lisrel PLS. Luxima Metro Media.

Henry, Nicholas. (2013). Public Administration and Public Affair, Pearson Education, Inc, United States,

Anwar Prabu Mngkunegara. (2009). "Manajemen Sumber Daya Manusia. Bandung: PT. Remaja Rosdakrya

Handoko, T. Hani. (2010). Manajemen Personalia dan Sumber Daya Manusia, Edisi kedua. Yogyakarta: BPFE UGM

Wibowo Sulaiman. (2014). Analisis Regresi Menggunakan SPSS Contoh kasus dan Pemecahannya. Yogyakarta: Andi
Stella. (2013). "Pengaruh Partisipasi Penyusunan Anggaran Terhadap Kinerja Manajerial: Kepuasan Kerja dan Job Relevant Information sebagai Variabel Intervening". Jurnal Bisnis dan Akuntansi, Vol. 15, No. 1, Juni, Hlm. 37-56.

Jimoh, A. M. (2008). "Emotional Labour, Conscientousness and Job Tenure as Predictors of Job Performance Among University Administrative Workers in Southwestern Nigerian". International Journal of African \& African Studies, Vol. VII, No. 2.

Davis, Keith \& John Newstrom. (2004). Perilaku Dalam Organisasi. Ed. Ketujuh. Jakarta: Erlangga.

Hoque, Zahirul dan Peter Brosnan. (2007). Aligning Industrial Relations Risk, Budgetary Participation, and Budgeting Meaures of Performance: Impact on Managerial Performance. SSRN.

Mahmudi. (2005). Manajemen Kinerja Sektor Publik, Yogyakarta, UPP AMP YKPN.

Desiana, PM. Dan B.W. Soetjipto. (2006). "Pengaruh Role Stressor, Persepsi Dukungan Organisasi Terhadap Kepuasan Kerja dan Komitmen. Usahawan", No.05 Th XXXV: 22-32

Sugiyono. (2010). Metode Penelitian Kuantitatif, Kualitatif dan $R \& D$. Bandung: Alfabeta

Nengsy, Herda., Sari, Ria Nelly., Agusti, Restu. (2013). Pengaruh Partisipasi Penyusunan Anggaran Terhadap Kinerja Manajerial dengan Job Relevant Information, Kepuasan Kerja, dan Motivasi sebagai Variabel Intervenig. Jurnal Akuntansi. Vol. 2. No. 1, Oktober, Hal 1-17.

Greenberg, jerld dan Robert Baron. (2003). Behavior in Organizations (understanding and mnging the human side of work). Eight Edition: Prentice Hall

Winnetouw, Adiko. (2008). Pengaruh Kepuasan Terhadap Kinerja Karyawan Operasional Rothabama Event Organizer di Surabaya

Mardiasmo. (2006). Akuntansi Sektor Publik. Yogyakarta: ANDI 